\title{
PHYTOCHEMICAL AND PHYSICOCHEMICAL ANALYSIS OF MICROWAVE-ASSISTED EXTRACTION CORIANDRUM SATIVUM L. LEAVES AND ITS BIOLOGICAL EVALUATION
}

\author{
SAMREEN FATEMA ${ }^{1}$, MAZAHAR FAROOQUI ${ }^{2}$, PATHAN MOHD ARIF ${ }^{1}$, SYED UMMUL KHAIR ASEMA ${ }^{1 *}$ \\ ${ }^{1}$ Research Center, Maulana Azad College, Aurangabad, Maharashtra, India. ${ }^{2}$ Department of Dr. Rafiq Zakaria College for Women, \\ Aurangabad, Maharashtra, India. Email: ukasema@gmail.com
}

Received: 17 February 2018, Revised and Accepted: 10 April 2019

\section{ABSTRACT}

Objective: The main objective of the present work is to carry out the phytochemical constituent present and physicochemical analysis of microwaveassisted extract (MAE) of Coriandrum sativum leaves and to investigate its antibacterial activity.

Methods: The powdered samples of the leaves were extracted and analyzed for physicochemical properties. Extraction was carried out for C. sativum using different solvents and used for phytochemical investigation. Infrared (IR) spectrum and antibacterial activity of MAE were carried out.

Results: The results show that the percentage extract is different in the different solvents and also differs in phytochemical constituents. Phytochemicals present in the MAE also confirmed by IR spectroscopy. MAE is active against bacteria.

Conclusion: The phytochemicals present in C. sativum is confirmed by IR spectrum and these phytochemicals responsible for antibacterial activity.

Keywords: Coriandrum sativum, Microwave-assisted extraction, Phytochemicals, Physicochemical property, Antibacterial activity.

(c) 2019 The Authors. Published by Innovare Academic Sciences Pvt Ltd. This is an open access article under the CC BY license (http://creativecommons. org/licenses/by/4. 0/) DOI: http://dx.doi.org/10.22159/ajpcr.2019.v12i5.32648

\section{INTRODUCTION}

Plants having great potential to produce compounds with different drug activity, through which humans can take benefit for the healthy life. Several infectious diseases can be treated with the traditional remedies [1]. From ancient time, humans are habitual to utilize plants and plant-derived products to cure and relief from physical and mental illness [2]. The potential of higher plants is the source of drugs and these are still unexplored [3]. Near about 120 active compounds have been isolated from the higher plants widely used in modern medicine and $80 \%$ shows a positive correlation between their therapeutic use and traditional plants from which they derived [4]. From the past few years, researcher's interest has been increased toward the plant constituents all over the world and evidences are collected to show immense potential of medicinal plants used in various traditional systems [5]. Microwave-assisted extraction has many advantages over conventional extraction such as it requires shorter extraction time, lesser solvent consumption, higher extraction rate, and better product with the lowest cost [6].

Coriandrum sativum L. belongs to the Umbelliferae-Apiaceae family [7] commonly known as coriander in English and Dhaniyaa in Hindi [8]. India is the world's largest coriander producer [9]. The seeds and leaves of this spice are widely used for various food applications; the aromatic coriander leaves are used as flavoring to the dishes such as spread in bread, soup, curry, fish, and meat sauce [10]. C. sativum L. has been reported to have important medicinal value as antioxidant $[11,12]$, antifungal [13], anti-inflammatory [14], anxiolytic and analgesic [15], antitumor [16], and antidiabetic [17]. The present study is for the analysis of $C$. sativum L. for its physicochemical and phytochemical analysis and its biological evaluation from Aurangabad region.

\section{METHODS}

The leaves of C. sativum L. were collected from local market of Aurangabad city. The plant is identified as C. sativum L. and index in herbarium Dr. Bamu. The leaves were washed and kept for drying at room temperature under shade for 1 week. The dried sample was collected and grind using kitchen grinder. The powder sample is used for the extraction and analysis.

The procedure for the physical parameters of the powder such as fluorescence test ash analysis, bulk density, tap density, and other parameters is measured as mentioned in literature [18]. The physical parameters such as relative density, surface tension, viscosity, and refractive index were measured [19]. Qualitative test for alkaloids, carbohydrate, proteins, tannins, saponins, etc., was carried [20]. Spectral analysis and antibacterial activity are also investigated for the microwave-assisted extract (MAE).

\section{RESULTS AND DISCUSSION}

\section{Fluorescent test}

The powdered samples were treated with different chemicals and observed with naked eyes. The results are summarized in Table 1. It is observed that the

\section{Ash value}

The total ash content of the powder is formed to be $8.5 \%$. The acidinsoluble ash was found to be $41 \%$, whereas water-soluble as $16 \%$. The ash is mostly consisting of transition elements, i.e., cobalt or magnesium. The tapped density and bulk density of the powdered material is found to be 0.5647 and 0.4078 , respectively. Carr's index and Hausner's ratio calculated and are found to be $24.68 \%$ and 1.3847 , respectively. The results of the present study are given in Table 2 .

\section{Extractive values}

The leaves of $C$. sativum were extracted using three different solvents, i.e., aqueous, ether, and alcohol extract. Out of which for aqueous microwave radiations are used for extraction. Ether and alcohol extraction conventional method are used. Of all three extracts, microwave gives more percent of extract. Percentages of all three extract are given in Table 3. 
Phytochemical analysis

Phytochemicals are the secondary metabolites, which are responsible for primary medicinal value. These are non-essential nutrients but required for healthy life. Plants produced these chemicals to protect themselves against bacteria. All three extracts of $C$. sativum were analyzed for phytochemical constituents such as alkaloids, carbohydrates, proteins, and amino acids. The results are shown in Table 4.

Table 1: Florescent test for leave powder

\begin{tabular}{lll}
\hline S. No. & Solutions & Observation \\
\hline 1 & Powder as such (P) & Dark green \\
2 & P+ammonia & Green \\
3 & P+Conc. $\mathrm{HCl}$ & Dark green \\
4 & $\mathrm{P}+$ Conc. $\mathrm{HNO}_{3}$ & Dark orange \\
5 & $\mathrm{P}+$ Conc. $\mathrm{H}_{2} \mathrm{SO}_{4}$ & Black \\
6 & $\mathrm{P}+$ Chloroform & Fluorescent green \\
7 & $\mathrm{P}+\mathrm{Glacial}$ acetic acid & Whitish-green \\
8 & $\mathrm{P}+2 \mathrm{~N} \mathrm{acetic} \mathrm{acid}$ & Whitish-green \\
9 & $\mathrm{P}+2 \mathrm{~N} \mathrm{HCl}_{10}$ & Whitish-green \\
11 & $\mathrm{P}+2 \mathrm{~N} \mathrm{NaOH}_{2}$ & Brownish-yellow \\
\hline
\end{tabular}

Table 2: Ash analysis and densities of leave powder

\begin{tabular}{lll}
\hline S. No. & Ash & Results \\
\hline 1 & Total ash & $8.5 \%$ \\
2 & Acid insoluble & $41 \%$ \\
3 & Water soluble & $16 \%$ \\
4 & Bulk density & 0.4078 \\
5 & Tapped density & 0.5647 \\
6 & Hausner ratio & 1.3847 \\
7. & Carr's index & $24.68 \%$ \\
\hline
\end{tabular}

Table 3: Extractive value of $C$. sativum plant leaves

\begin{tabular}{lll}
\hline S. No. & Solvent & $\mathbf{\%}$ \\
\hline 1 & Alcohol extract & 19.25 \\
2 & Ether extract & 11.86 \\
3 & Microwave-assisted hydroextraction & 30.56 \\
\hline C. sativum: Coriandrum sativum
\end{tabular}

Table 4: Qualitative test for $C$. sativum leaves extract

\begin{tabular}{|c|c|c|c|c|}
\hline S. No. & Reagent & $\mathbf{A E}$ & EE & MAE \\
\hline 1 & Detection of alkaloids & & & \\
\hline $\mathrm{A}$ & Mayer's test & -ve & -ve & -ve \\
\hline $\mathrm{B}$ & Wagner's test & + ve & + ve & +ve \\
\hline $\mathrm{C}$ & Hager's test & + ve & -ve & +ve \\
\hline 2 & Detection of carbohydrate & & & \\
\hline A & Molisch test & + ve & $+\mathrm{ve}$ & +ve \\
\hline $\mathrm{B}$ & Fehling's test & + ve & + ve & +ve \\
\hline $\mathrm{C}$ & Benedict test & $+\mathrm{ve}$ & -ve & +ve \\
\hline $\mathrm{D}$ & Barfoed's test & + ve & $+\mathrm{ve}$ & -ve \\
\hline 3 & Detection of glycosides & & & \\
\hline A & Borntrager's test & - ve & - ve & - ve \\
\hline $\mathrm{B}$ & Legal's test & - ve & -ve & - ve \\
\hline 4 & Saponin & - ve & - ve & +ve \\
\hline 5 & Detection of proteins and a & ino ac & & \\
\hline A & Millon's test & - ve & - ve & - ve \\
\hline $\mathrm{B}$ & Nitric acid test & - ve & $+\mathrm{ve}$ & - ve \\
\hline $\mathrm{C}$ & Biuret test & - ve & $-\mathrm{ve}$ & - ve \\
\hline $\mathrm{D}$ & Ninhydrin test & - ve & -ve & - ve \\
\hline 6 & Detection of phenolic comp & und a & nnins & \\
\hline $\mathrm{A}$ & Ferric chloride test & $+\mathrm{ve}$ & - ve & +ve \\
\hline $\mathrm{B}$ & Gelatin test & - ve & $+\mathrm{ve}$ & +ve \\
\hline $\mathrm{C}$ & Lead acetate test & + ve & - ve & +ve \\
\hline $\mathrm{D}$ & Alkaline reagent test & + ve & -ve & +ve \\
\hline
\end{tabular}

AE: Alcohol extract, EE: Ether extract, MAE: Microwave-assisted extract,

C. sativum: Coriandrum sativum
Table 5: Antibacterial properties of leaves extract

\begin{tabular}{lll}
\hline S. No. & Bacteria & MAE \\
\hline 1 & E. coli & Active \\
2 & B. subtilis & Active \\
3 & S. typhi & Inactive \\
4 & S. aureus & Active \\
\hline S. typhi: Salmonella typhi, E. coli: Escherichia coli, B. subtilis: Bacillus subtilis, \\
S. aureus: Staphylococcus aureus
\end{tabular}

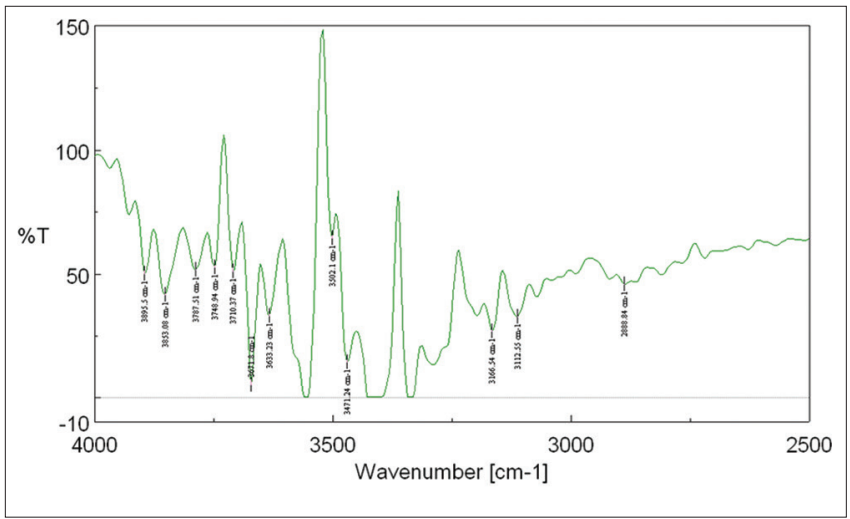

Fig. 1: Infrare spectrum of Coriandrum sativum L. leave extract

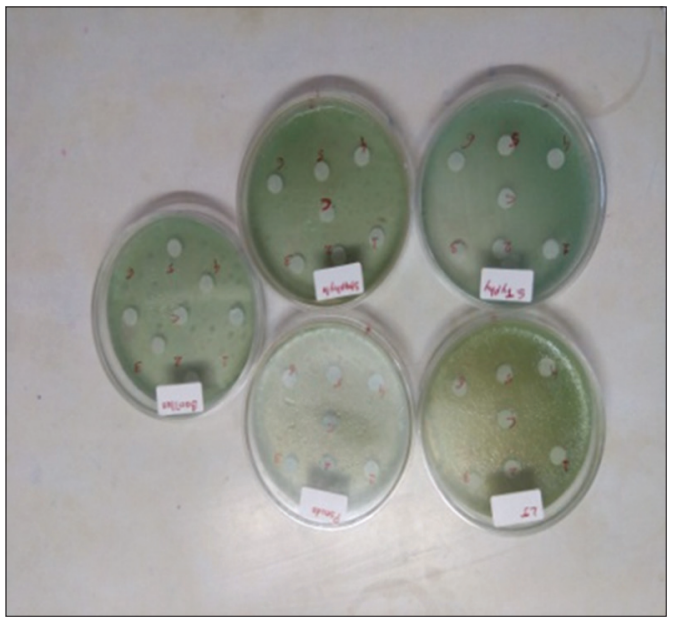

Fig. 2: Zone of inhibition of Coriandrum sativum L. leave extract

\section{Fourier-transform infrared (FTIR) spectrum}

The infrared (IR) spectrum of the extract of $C$. sativum was recorded on FTIR instrument IRT3000, JASCO, having serial no. B051061016 (Fig. 5). Though it contains a mixture of compounds but still in order to find out various functional groups and a finger print of samples. There are various IR bands observed. This represents that the various functional groups present in the plant extract. Unassociated hydroxyl groups show sharp absorption between 3700 and $3500 \mathrm{~cm}^{-1}$. 15 alkaloids contain hydroxyl groups, out of these 13 produce sharp bands in the region of $3625-3540 \mathrm{~cm}^{-1}[21] .3500-3300 \mathrm{~cm}^{-1}$ represents the presence of $\mathrm{N}-\mathrm{H}$ group of secondary amine. The band between 3155 and 3050 $\mathrm{cm}^{-1}$ is for $\mathrm{C}-\mathrm{H}$ stretching and the absorption between 3050 and 2880 $\mathrm{cm}^{-1}$ is for methane.

Antibacterial activity

Bacteria are the oldest forms of life which exist in the universe. Biologically the bacterium cell, there is the capsule, cell wall, and cell membrane, in which cytoplasm and at times endosperms are enclosed. The extracts are screened for the antibacterial activity. We observed that MAE is active against all tested bacteria but inactive against Salmonella typhi. 


\section{CONCLUSION}

The present study revealed that the powder solution gives different color in different solvent. The percentage of inorganic material in the form of total ash is $8.5 \%$. While acid insoluble ash is $41 \%$ and water soluble $16 \%$. While tapped density and bulk density are the density of the powder itself and Carr's index is the parameter which shows the flowability of the powder. Coriandrum sativum L. is having good flowability because its Carr's index is $<25 \%$. The powder of plant leaves was extracted by three different solvents, that is, alcohol, ether, and aqueous extract. For aqueous extract, microwave is used as energy supplier. The percentage of MAE is high as compare with other solvent extraction. Qualitative phytochemical test shows the presence of alkaloids, carbohydrate, and phenolic compounds which were further confirm by infrared spectroscopy. The extract is also active against Escherichia coli, Bacillus subtilis, and Staphylococcus aureus but inactive against $S$. typhi.

\section{ACKNOWLEDGMENT}

One of the author Syed Ummul Khair Asema is thankful to the Dr. Babasaheb Ambedkar Marathwada University for financial support.

\section{AUTHORS' CONTRIBUTIONS}

Samreen Fatema (SF), Mazahar Farooqui (MF), Pathan Mohd Arif (PMA), and Syed Ummulkhair Asema (SUA) designed the analysis. SF and SUA collected the data. SUA and SF performed the analysis and wrote the paper. Analytic calculations are performed by all the authors. Pathan Mohd Arif (PMA) and Mazahar Farooqui (MF) corrected and verified the paper

\section{CONFLICTS OF INTEREST}

No conflicts of interest exist in the present investigation.

\section{REFERENCES}

1. Fatema S, Farooqui M, Gawade B, Arif PM. Screening of antioxidant property and phytochemical constituents of ethereal extract of Vitex negundo Linn leaves. Int J ChemTech Res 2018;11:188-92.

2. Sekar DK, Kumar G, Karthik L, Rao KV. A review on pharmacological and phytochemical properties of Aegle marmelos (L) Corr. Serr (Rutacceae). Asian J Plant Sci Res 2011;1:8-17.

3. Mahesh B, Satish S. Antimicrobial activity of some important medicinal plant against plant and human pathogen. World J Agric Sci 2008;4:839-43.

4. Iqbal PJ. Phytochemical screening of certain plant species of Agra city. J Drug Deliv Ther 2012;2:135-8.

5. Makhija IK, Sharma IP, Khamar D. Phytochemical and pharmacologiacal properties of Ficus religiosa an overview. Ann Biol Res 2010;1:171-80.

6. Dhobi M, Mandal V, Hemaltha S. Optimization of microwave assisted extraction of bioactive flavonolignan silybinin. J Chem Metrol 2009;3:13-29

7. Ayfer D, Erdogrul OT. Antimicrobial activities of various medicinal and commercial plant extracts. Turk J Biol 2003;27:157-62.

8. Deepa B, Anuradha CV. Antioxidant potential of Coriandrum sativam L. seed extract. Indian J Exp Biol 2011;49:30-8.

9. Anwar F, Sulman M, Hussain AI, Saari N, Iqbal S, Rashid U. Physicochemical composition of hydro-distilled essential oil from coriander (Coriandrum sativum L.) seeds sultivated in Pakistan. J Med Plants Res 2011;5:3537-44.

10. Guler T, Ertas ON, Ciftci M, Dalkilic B. The effect of coriander seed (Coriandrum sativum L.) as diet ingredient on the performance of Japanese quil. South Afr J Anim Sci 2005;35:4.

11. de Almeida Melo E, Filho JM, Guerra NB. Characterization of antioxidant compounds in aqueous coriander extract (Coriandrum sativum L.). Lebensm Wiss. U Technology 2005;38:15-9.

12. de Almeida Melo E, Bion FM, Filho JM, Guerra NB. In vivo antioxidant effect of aqueous and etheric coriander (Coriandrum sativum L.) extracts. Eur J Lipid Sci Technol 2003;105:483-7.

13. Darughe F, Barzegar M, Sahari M. Antioxidant and antifungal activity of Coriander (Coriandrum sativam L.) Essential oil in cake. Int Food Res J 2012;19:1253-60.

14. Sonika G, Manubala R, Deepak J. Comparative studies on antiinflammatory activity of Coriandrum sativum, Datura stramonium and Azadirachta indica. Asian J Exp Biol Sci 2010;1:151-4.

15. Pathan AR, Kothawade KA, Logade MN. Anxiolytic and analgesic effect of seeds of Coriandrum sativum Linn. Int J Res Pharm Chem 2011;1:1087-99.

16. Gomez-Flores R, Hernandez-Martinez H, Tamez-Guerra P, TamezGuerra R, Quintanilla-Licea R. Antitumor and immunomodulating potential of Coriandrum sativum, Piper nigrum and Cinnamomum zeylanicum. J Nat Prod 2010;3:54-63.

17. Gray AM, Flatt PR. Insulin-releasing and insulin-like activity of the traditional anti-diabetic plant Coriandrum sativum (coriander). Br J Nutr 1999;81:203-9.

18. Fatema S, Farooqui M, Jadhav S, Arif PM. Phytochemical and physicochemical analysis of conventional and microwave assisted extraction of Vitex negundo Linn leaves. Indo Am J Pharm Sci 2018;5:6057-65

19. Basa'ar O, Fatema S, Alrabie A, Farooqui M. Supercritical fluid extraction of Cichorium intybus (L) and it's characterization. J Chem Pharm Sci 2016;9:2936-44

20. Fatema S, Basa'ar O, Farooqui M, Arif PM. Phytochemical and physicochemical properties of Hibiscus rosa-sinensis leaves extract: A comparison between conventional and microwave assisted extraction. Eur J Biomed Pharm Sci 2018;5:551-9.

21. Marion BY, Ramsay DA, Jones RN. The infrared absorption spectra of alkaloids. J Am Chem Soc 1951;73:305-8. 